\title{
PENGGUNAAN METODE SIMULASI MELALUI GAMBAR PETA UNTUK MENINGKATKAN HASIL BELAJAR ILMU PENGETAHUAN SOSIAL (IPS) SISWA KELAS VI DI SEKOLAH DASAR ISLAM (SDI) AL BAYYINAH CIPEDAK JAGAKARSA JAKARTA SELATAN
}

\author{
Nama : Sugiyarti \\ Nim: 836366609 \\ Email: sugiyarti341@gmail.com
}

\begin{abstract}
ABSTRAK
Penelitian Tindakan Kelas ini dilaksanakan di SDI Al Bayyinah Cipedak Jagakarsa Jakarta Selatan kelas VI yang berjumlah 25 orang. Tujuan penelitian ini untuk meningkatkan hasil belajar peserta didik kelas VI pada mata pelajaran Ilmu Pengetahuan Sosial tentang Negara-negara tetangga di kawasan Asia Tenggara dengan menggunakan metode simulasi melalui media gambar peta. Pada pembelajaran prasiklus dengan KKM 70 dari jumlah 25 peserta didik diperileh hasil rerata peserta didik 61,46 dan peserta didik yang mencapai KKM 8 orang atau $32 \%$. Sedangkan melalui pengamatan peserta didik yang dapat menjawab pertanyaan guru hanya ada 8 peserta didik (32\%). Siklus I hasil rerata peserta didik 67,56 yang belum mencapai KKM berjumlah 12 peserta didik atau $48 \%$. Melalui data pengamatan peserta didik yang dapat menjawab pertanyaan guru hanya 13 orang atau $52 \%$. Pada siklus II diperoleh hasil rerata peserta didik 76,96 peserta didik yang mencapai KKM berjumlah 21 orang atau $84 \%$. Sedangkan data pengamatan peserta didik yang dapat menjawab pertanyaan guru berjumlah 21 orang atau $84 \%$. Penerapan metode simulasi melalui gambar peta telah memberikan pengaruh yang sangat baik dengan meningkatnya hasil belajar dan motivasi peserta didik.
\end{abstract}

Kata-kata kunci: hasil belajar IPS, metode simulasi, media gambar.

\section{PENDAHULUAN}

\section{A. Latar Belakang Masalah}

Sekolah adalah lembaga pendidikan formal. Di tempat inilah kegiatan belajar mengajar berlangsung. Ilmu pengetahuan yang diajarkan dan dikembangkan kepada para peserta didik. Para guru dan peserta didik terlihat secara interaktif dalam proses pembelajaran.

Pada prinsipnya, pembelajaran IPS di sekolah dasar merupakan suatu proses kegiatan pembelajaran dengan tujuan pokok menanamkan nilai-nilai 
(value) kepada peserta didik agar mereka memiliki karakter dan kepribadian yang mandiri, yang dapat mempertanggungjawabkan keputusan yang diambil secara mandiri. Tujuan itu dapat tercapai apabila proses pembelajaran IPS di sekolah dasar dilakukan dengan penggunaan metode dan media pembelajaran yang tepat. Dimana mutu pendidikan di sekolah sangat ditentukan pada bagaimana proses pembelajaran yang berlangsung di kelas dapat dilaksanakan dengan baik.

Dari proses pembelajaran yang baik itulah diharapkan semua peserta didik dapat mencapai kompetensi yang diharapkan. Walaupun pada kenyataannya berdasarkan penelitian dan observasi menunjukkan bahwa hasil evaluasi belajar peserta didik kelas VI Sekolah Dasar Islam (SDI) Al Bayyinah Cipedak Jakarta Selatan pada mata pelajaran IPS dengan materi "Negara-nagara tetangga di kawasan Asia Tenggara" masih rendah. Adapun perinciannya sebagai berikut, Kriteria Ketuntasan Minimal (KKM) 70. Jumlah peserta didik 25 orang. 8 orang mencapai KKM atau 32\%. Sedangkan 17 orang masih di bawah KKM atau 68\%, dengan nilai rerata 61,4.

Hal-hal di atas bisa saja terjadi ketika pembelajaran berjalan monoton dan pasif, di mana peserta didik hanya mendengarkan, mencatat dan menjawab pertanyaan. Oleh karena itu, ada hal lain yang harus diperhatikan oleh guru sebagai pengajar agar pembelajaran tersebut menjadi aktif, komunikatif dan efektif. Sehingga guru bukan sebagai penguasa kelas akan tetapi menjadi pasilitator yang dapat mempasilitasi peserta didik agar dapat belajar dengan sebaik-baiknya. Hal yang dimaksud adalah penggunaan metode dan media belajar.

Banyak ragam metode pembelajaran yang dapat digunakan, seperti metode ceramah, tanya jawab, diskusi, inquiri, demonstrasi, simulasi, unjuk kerja, percobaan dan metode-metode lainnya yang biasa digunakan. Tetapi guru harus mampu memilih metode yang tepat untuk menyampaikan materi ajar sesuai kebutuhan. Sehingga dengan metode yang tepat dapat membantu peserta didik dalam memahami materi yang diajarkan. 
Dalam pembelajaran ternyata tidak cukup dengan metode saja, media pembelajaran juga dapat menunjang keberhasilan dalam mencapai kompetensi yang diharapkan. Di sinilah peran guru dalam menciptakan suasana belajar yang menarik dituntut untuk kreatif menemukan media pembelajaran yang sekiranya mampu membantu peserta didik dalam memahami dan mencapai kompetensi belajar.

Berdasarkan latar belakang masalah di atas, peneliti tertarik mengadakan penelitian dengan judul "Meningkatkan Hasil Belajar Ilmu Pengetahuan Sosial tentang Negara-Negara Tetangga di Kawasan Asia Tenggara Pada Peserta Didik Kelas VI di Sekolah Dasar Islam (SDI) Al Bayyinah Cipedak Jagakarsa Jakarta Selatan dengan menggunakan Metode Simulasi Melalui Gambar Peta"

\section{Identifikasi Masalah}

Berdasarkan latar belakang masalah tersebut, dapat diidentifikasi beberapa masalah pada pembelajaran IPS yaitu ditemukan penyebab rendah hasil belajar peserta didik sebagai berikut:

a. Kurangnya pemahaman peserta didik terhadap materi yang diberikan.

b. Rendahnya hasil belajar peserta didik pada pelajaran IPS. Dari 25 orang peserta didik dengan KKM 70, hanya 8 orang yang mencapai KKM atau 32\%. Sedangkan 17 orang masih di bawah KKM atau 68\% dengan rerata 61,4 .

c. Penggunaan metode pembelajaran yang kurang variatif.

d. Kurang optimalnya penggunaan media pembelajaran

\section{Analisis Masalah}

Berdasarkan identifikasi masalah, refleksi dan hasil diskusi dengan teman sejawat diketahui penyebab dari masalah ini adalah:

a. Guru belum menggunakan metode pembelajaran dan teknik pembelajaran yang bervariasi dan efektif yang sesuai secara maksimal sehingga peserta didik mengalami kesulitan dalam belajar. 
b. Guru belum menggunakan media pembelajaran yang sesuai secara maksimal sehingga tidak terciptanya suasana pembelajaran yang kondusif, dan menyenangkan bagi peserta didik

c. Guru kurang memberikan motivasi pada saat pembelajaran berlangsung sehingga peserta didik tidak tertarik pada pelajaran IPS.

d. Guru kurang memberikan kesempatan kepada peserta didik untuk bertanya dan melibatkannya dalam proses pembelajaran.

\section{Alternatif Pemecahan Masalah}

Keberhasilan suatu proses pembelajaran dalam tercapainya hasil belajar yang diharapkan ditentukan oleh beberapa faktor, diantaranya pemilihan metode dan media pembelajaran yang tepat.

a. Guru sebaiknya menggunakan metode dan teknik pembelajaran yang bervariasi dan efektif sehingga diperoleh hasil belajar secara maksimal. dapat

b. Guru memanfaat media pembelajaran yang sesuai secara maksimal sehingga terciptanya suasana pembelajaran yang kondusif, dan menyenangkan bagi peserta didik

c. Guru memberikan motivasi pada saat pembelajaran berlangsung sehingga peserta didik tertarik pada pelajaran IPS.

d. Guru melibatkan peserta didik dalam pembelajaran, seperti memberi kesempatan bertanya, menjawab, menanggapi atau mempraktikan.

\section{B. Rumusan Masalah}

Berdasarkan identifikasi dan analisis masalah, hasil refleksi dan diskusi dengan teman sejawat tentang materi pembelajaran serta dengan materi pembelajaran yang dipaparkan di atas, dapat dirumuskan masalah adalah "Bagaimana Meningkatkan Hasil Belajar Ilmu Pengetahuan Sosial Tentang Negara-negara Tetangga di Kawasan Asia Tenggara dengan Metode Simulasi dan Media Gambar Peta di Kelas VI Sekolah Dasar Islam Al Bayyinah Cipedak Jagakarsa Jakarta Selatan?"

\section{Tujuan Penelitian Perbaikan Pembelajaran}


Selatan. proses pembelajaran dapat dikatakan berhasil apabila tujuan pembelajaran yang dilaksanakan dapat dipahami dan dikuasai peserta didik. Untuk mengetahui berhasil tidaknya proses pembelajaran, maka harus diadakan evaluasi.

Berdasarkan uraian dari rumusan maka tujuan utama penelitian perbaikan pembelajaran adalah untuk meningkatkan hasil belajar Ilmu Pengetahuan Sosial tentang negara-negara tetangga di kawasan Asia Tenggara dengan menggunakan metode simulasi dan media gambar peta pada peserta didik kelas VI di Sekolah Dasar Islam Islam Al Bayyinah Cipedak Jagakarsa Jakarta

\section{Manfaat Penelitian Perbaikan Pembelajaran}

Ada beberapa manfaat besar dari penelitian perbaikan pembelajaran dalam hal ini PTK (Penelitian Tindakan Kelas) baik bagi peserta didik, guru (peneliti), pembelajaran, maupun sekolah. Manfaat tersebut antara lain:

Manfaat penelitian perbaikan pembelajaran di susun dalam rangka peningkatan mutu pendidikan dan memberikan manfaat yang positif bagi berbagai pihak :

\section{Bagi peserta didik}

a. Dapat memotivasi peserta didik untuk belajar lebih giat khususnya dalam pembelajaran IPS sehingga mengurangi kebosanan dalam belajar.

b. Dapat mengembangkan rasa kebersamaan dan kerja sama peserta didik dengan peserta didik lain.

c. Membiasakan peserta didik berani tampil dan percaya diri.

\section{Bagi Guru}

a. Memperbaiki pembelajaran yang di kelola.

b. Dapat mengetahui masalah - masalah dan kesulitan yang di hadapi peserta didik dalam pembelajaran IPS.

c. Dapat meningkatkan kualitas pembelajaran.

\section{Bagi sekolah}


a. Meningkatkan mutu pelajaran IPS di kelas VI Sekolah Dasar Islam Al Bayyinah Cipedak Jagakarsa Jakarta Selatan.

b. Memberikan informasi kepada rekan-rekan guru tentang manfaat metode dan media pembelajaran dalam meningkatkan hasil belajar peserta didik.

c. Dapat meningkatkan kualitas pendidikan bagi peserta didik.

d. Mempunyai kesempatan yang besar untuk maju dan berkembang dengan pesat.

e. Adanya peningkatan kemampuan profesional para guru, perbaikan proses dan hasil belajar peserta didik, serta kondusifnya iklim pendidikan di sekolah tersebut.

\section{Untuk Peneliti:}

a. Sebagai pengalaman berharga bagi peneliti dalam mengaplikasikan ilmu pengetauan sehingga akan memperkaya khasanah pengetahuan penelitian untuk diamalkan.

b. Sebagai bahan acuan untuk menjadi lebih baik lagi.

\section{KAJIAN PUSTAKA}

\section{A. Hasil Belajar Ilmu Pengetahuan Sosial}

\section{Hasil Belajar}

Setiap manusia tidak terlepas dari keinginannya untuk mengembangkan diri, salah satu cara adalah melalui belajar, baik secara langsung maupun tidak langsung. Belajar merupakan suatu hal yang tidak dapat dipisahkan dalam kehidupan manusia. Melalui belajar orang menjadi tahu tentang hal-hal yang sebelumnya tidak diketahui dan untuk menambah pengetahuan yang sudah dimiliki. Belajar sebagai suatu perubahan tingkah laku dalam diri seseorang yang relatif menetap sebagai hasil dari sebuah pengalaman

Menurut Slameto (2003 : 2) bahwa belajar ialah "Suatu usaha yang dilakukan seseorang untuk memperoleh suatu perubahan tingkah laku yang baru secara keseluruhan, sebagai hasil pengalamannya sendiri dalam 
interaksi dengan lingkungannya. Sedangkan Gagne dalam Winataputra (2000 : 2.3) mengemukakan bahwa belajar adalah suatu proses dimana suatu organisma berubah perilakunya sebagai akibat dari pengalaman.

Selanjuntnya Syah, (2004 : 136) menambahkan dalam bukunya Psikologi Belajar bahwa belajar adalah "tahapan perubahan seluruh tingkah laku individu yang relatif menetap sebagai hasil pengalaman dan interaksi dengan lingkungan yang melibatkan proses kognitif". Winkel (1990:66), menyampaikan belajar adalah suatu aktifitas mental atau psikis yang berlangsung dalam suatu interaksi aktif dengan lingkungannya, yang menghasilkan perubahan-perubahan pengetahuan, pengalaman, keterampilan dan nilai sikap.

Menurut Abdurrahman (1999) dalam Jihad (2013 : 14), hasil belajar merupakan keluaran (outputs) dari suatu sistem pemrosesan masukan (input). Masukan dari sitem tersebut berupa bermacam-macam informasi sedangkan keluarannya adalah perbuatan atau kinerja (performance). Hasil belajar merupakan kulminasi dari suatu proses yang telah dilakukan dalam belajar. Hasil belajar harus menunjukkan suatu perubahan tingkah laku atau perolehan perilaku yang baru dari peserta didik yang bersifat menetap, fungsional, positif dan disadari (Anitah, $2014: 2.19$ ). Ada berbagai faktor yang dapat mempengaruhi proses dan hasil belajar peserta didik di sekolah yang secara garis bessarnya dapat dibagi dalam dua bagian yaitu faktor internal dan faktor eksternal peserta didik. (Sabri, 1995 : 59). Faktor-faktor yang berasal dari luar diri peserta didik (eksternal) terdiri dari faktor lingkungan dan faktor instrumental. Sedangkan faktorfaktor yang berasal dari dalam diri peserta didik (internal); adalah berupa faktor fisiologis dan psikologis pada diri peserta didik.

Benyamin S. Bloom dalam Anni (2006 : 7), dan Sanjaya (2009 : 127-128) menyampaikan hasil belajar peserta didik mencakup tiga ranah belajar yaituMenurut dapada umumnya hasil belajar dapat dikelompokkan menjadi tiga ranah, yaitu kognitif, afektif, dan psikomotor. 
Pada dasarnya dalam proses pendidikan peserta didik merupakan bahan mentah (input) yang akan mengalami pemprosesan dan akan menghasilkan lulusan. Menurut Badudu yang dikutip oleh Pasaribu dalam bukunya yang berjudul Proses Belajar Mengajar (1993) prestasi atau hasil belajar adalah perolehan atau nilai yang dicapai oleh peserta didik yang sebelumnya harus mengikuti aktivitas belajar berdasarkan proses kegiatan yang telah diserapkan. Selanjutnya menurut Anitah (2009 : 1.5) hasil belajar berupa perubahan perilaku atau tingkah laku. Seseorang yang belajar akan berubah atau bertambah perilakunya, baik yang berupa pengetahuan, keterampilan, atau penguasaan nilai-nilai (sikap).

Berdasarkan pengertian para ahli diatas, penulis menyimpulkan bahwa hasil belajar adalah perolehan nilai yang dicapai ataupun dapat berupa perubahan tingkah laku baik berupa pengetahuan, keterampilan, ataupun penguasaan nilai-nilai (sikap) setelah mengikuti aktivitas belajar.

\section{Hakikat Ilmu Pengetahuan Sosial}

Menurut Supriya (2009 : 19) IPS merupakan nama mata pelajaran di tingkat sekolah dasar dan menengah atau nama program studi di perguruan tinggi identik dengan istilah "social studies". Selanjutnya menurut Barr, Bart dan Shermis, (1977 : 1-2) dalam Winaputra (2010 : 1.3) menyampaikan bahwa pemikiran mengenai konsep Ilmu Pengetahuan Sosial di Indonesia banyak dipengaruhi oleh pemikiran "sosial studies" di Amerika Serikat. Pilar historis-epistemologis, "Sosial Studies" pertama kali disampaikan oleh Edgar Bruce Wesley bahwa studi sosial adalah ilmu-ilmu yang disederhanakan untuk tujuan pendidikan (Barr, Bart dan Shermis, 1977: 1-2 dalam Winaputra 2010: 1.3).

Ahmadi (2009 : 3) menjelaskan bahwa Ilmu Pengetahuan Sosial adalah ilmu-ilmu sosial yang dipilih dan disesuaikan bagi program pendidikan di sekolah atau bagi kelompok belajar yang sederajat. Di dalam berisi seperangkat fakta, peristiwa, konsep, generalisasi yang berkaitan dengan perilaku manusia untuk membangun dirinya, masyarakat, bangsa dan lingkungannya. Berdasarkan kepada pengalaman masa lampau yang 
dapat dimaknai untuk masa kini dan diantisipasi untuk masa yang akan datang.

Konsep IPS masuk ke dalam dunia pendidikan di Indonesia pada tahun 1972 - 1973, yakni dalam kurikulum IPS di Indonesia, jenjang pendidikan SD dan SMP, pendidikan IPS dilakukan secara terpadu, sementara pada jenjang SMA, pendidikan IPS sudah mulai di partisi menjadi beberapa bidang kajian, yaitu sejarah, ekonomi, sosiologi dan geografi. Pada kurikulum 1994 ditambah dengan bidang kajian Tata Negara dan Antropologi. Dalam penelitian ini pendidikan IPS di SMA digunakan istilah bidang studi IPS dan mengacu pada kurikulum yang berlaku di SMA saat ini yaitu meliputi mata pelajaran sejarah, ekonomi, sosiologi dan geografi. Sedangkan dalam kurikulum KTSP tahun 2006 IPS di SMK adalah terpadu (Wahab, 2008 : 2.19). Kurikulum IPS tahun 2006 bertujuan agar peserta didik memiliki kemampuan sebagai berikut .

1) Mengenal konsep-konsep yang berkaitan dengan kehidupan masyarakat dan lingkungan.

2) Memiliki kemampuan dasar untuk berpikir logis dan kritis, rasa ingin tahu, memecahkan masalah, dan keterampilan dalam kehidupan sosial.

3) Memiliki komitmen dan kesadaran terhadap nilai-nilai sosial dan kemanusiaan.

4) Memiliki kemampuan berkomunikasi, bekerja sama dan berkompetisi dalam masyarakat yan majemuk, di tingkat lokal, nasional, dan global (Sardiyo, 2009 : 1.26).

Dengan demikian IPS adalah mata pelajaran yang dijarkan disetiap jenjang pendidikan termasuk di SD dengan bahan kajian terpadu yang merupakan penyederhanaan, adaptasi, seleksi dan modifikasi diorganisasikan dari konsep-konsep ketrampilan-ketrampilan Sejarah, Geografi, Sosiologi, Antropologi, dan Ekonomi,

Sehingga hasil belajar IPS adalah kemampuan-kemampuan yang dimiliki peserta didik setelah menerima pengalaman belajarnya dalam 
penyederhanaan, adaptasi, seleksi dan modifikasi diorganisasikan dari konsep-konsep ketrampilan-ketrampilan Sejarah, Geografi, Sosiologi, Antropologi, dan Ekonomi. kemampuan-kemampuan tersebut mencakup aspek kognitif, afektif, dan psikomotorik.

\section{B. Hakikat Metode Simulasi}

Dalam kamus umum Bahasa Indonesia, metode artinya cara yang telah diatur dan terpikir baik-baik untuk mencapai suatu maksud. (Poerwodarminto, 2005 : 767). Slameto (2010:82) mengemukakan, metode adalah cara atau jalan yang harus dilalui untuk mencapai suatu tujuan tertentu. Menurut Syaiful Bahri Djamarah dan Aswan Zain ( 2010 : 46), metode adalah suatu cara yang digunakan untuk mencapai tujuan yang telah ditetapkan.

Mulyani Sumantri dan Johar Permana (1998/1999: 161) metode simulasi diartikan sebagai cara penyajian pengajaran dengan menggunakan situasi tiruan untuk menggambarkan situasi sebenarnya agar diperoleh pemahaman tentang hakikat suatu konsep, prinsip, atau keterampilan tertentu. Sementara itu Hasibuan dan Mudjiono (1986: 27) simulasi adalah tiruan atau perbuatan yang hanya pura-pura saja, dari kata simulate yang artinya pura pura atau berbuat seolah-olah dan simulation artinya tiruan atau perbuatan yang hanya pura-pura saja. Simulasi dapat berupa role playing, psikodrama, sosiodrama dan permainan.

Hal senada juga dinyatakan oleh Ali (1983: 83) bahwa simulasi dapat diartikan sebagai suatu cara pengajaran dengan melakukan proses tingkah laku secara tiruan. Simulasi pada dasarnya semacam permainan dalam pengajaran yang diangkat dari realita kehidupan. Tujuannya untuk memberikan pemahaman tentang sesuatu konsep atau prinsip atau dapat juga untuk melatih kemampuan memecahkan masalah yang bersumber dari realita kehidupan.

Sa'ud (2005: 129) simulasi adalah sebuah replikasi atau visualisasi dari perilaku sebuah sistem, misalnya sebuah perencanaan pendidikan, yang berjalan pada kurun waktu yang tertentu. Jadi dapat dikatakan bahwa simulasi 
itu adalah sebuah model yang berisi seperangkat variabel yang menampilkan ciri utama dari sistem kehidupan yang sebenarnya. Simulasi memungkinkan keputusan-keputusan yang menentukan bagaimana ciri-ciri utama itu bisa dimodifikasi secara nyata.

Anitah, (2014: 5.22) metode simulasi merupakan salah satu metode pembelajaran yang dapat digunakan dalam pembelajaran kelompok. Proses pembelajaran yang menggunakan metode simulasi cenderung objeknya bukan benda atau kegiatan yang sebenarnya, melainkan kegiatan mengajar yang bersifat pura-pura. Kegiatan simulasi dapat dilakukan oleh peserta didik pada kelas

Hal senada juga disampaikan Uno (2007: 29) ada empat prinsip yang harus dipegang oleh guru/fasilitator, antara lain :

1. Penjelasan, untuk melakukan simulasi pemain harus benar-benar memahami aturan main. Oleh karena itu guru hendaknya memberikan penjelasaan dengan sejelas jelasnya tentang aktivitas yang harus dilakukan berikut konsekuensi-konsekuensinya.

2. Mengawasi (refereeing), simulasi dirancang untuk tujuan tertentu dengan aturan dan prosedur main tertentu. Oleh karena itu guru harus mengawasi proses simulasi sehingga berjalan sebagaimana seharusnya.

3. Melatih (coaching), dalam simulasi pemain akan mengalami kesalahan. Oleh karena itu guru harus memberikan saran, petunjuk, atau arahan sehingga memungkinkan mereka tidak melakukan kesalahan yang sama

4. Diskusi, dalam refleksi mejadi sangat penting. Oleh karena itu setelah selesai simulasi selesai guru mendiskusikan bebrapa hal, seperti: (1) seberapa jauh simulasi sudah sesuai dengan situasi nyata (real word); (2) kesulitan- kesulitan; (3) hikmah apa yang dapat diambil dari simulasi; dan (4) bagaimana memperbaiki/meningkatkan kemampuan simulasi,dll.

Sementara itu, Hamalik (2002: 199) menyatakan bahwa tujuan bermain peran, sesuai dengan jenis belajar adalah :

1. Belajar dengan berbuat. Para peserta didik melakukan peranan tertentu sesuai dengan kenyataan yang sesunguhnya. Tujuannya untuk 
mengembangkan keterampilan-keterampilan interaktif atau keterampilan-keterampilan reaktif.

2. Belajar melalui peniruan (imitasi). Para siwa pengamat drama menyamakan diri dengan pelaku (aktor) dan tingkah laku mereka.

3. Belajar melalui balika. Para pengamat mengomentari (menanggapi) perilaku para pemain/pemegang peran yang telah ditampilkan. Tujuannya untuk mengembangkan prosedur-prosedur kognitif dan prinsip-prinsip yang mendasari perilaku keterampilan yang telah didramatisasikan.

4. Belajar melalui pengkajian, penilaian, dan pengulangan. Para peserta dapat memperbaiki keterampilan-keterampilan mereka dengan mengulanginya dalam penampilan berikut.

Taniredja (2011: 40-41) metode simulasi memiliki kelebihan, yaitu :

1. Menyenangkan sehingga peserta didik secara wajar terdorong untuk berpartisipasi.

2. Menggalakkan guru untuk mengembangkan aktivitas simulasi

3. Memungkinkan eksperimen berlangsung tanpa memerlukan lingkungan yang sebenarnya

4. Memvisualkan hal-hal yang abstrak

5. Tidak memerlukan keterampilan komunikasi yang pelik

6. Memungkinkan terjadinya interaksi antarpeserta didik

7. Menimbulkan respon yang positif dari peserta didik yang lamban, kurang cakap, dan kurang motivasi

8. Melatih berfikir kritis karena peserta didik terlibat dalam analisa proses, kemajuan simulasi.

Menurut Joyce dan Weil (1986) dan (Winataputra, 2001: 66) metode pembelajaran simulasi ini memiliki tahap sebagai berikut :

1. Tahap Orientasi

a. Menyajikan berbagai topik simulasi dan konsep-konsep yang akan diintegrasikan dalam proses simulasi

b. Menjelaskan prinsip simulasi dan permainan

c. Memberikan gambaran teknis secara umum tentang proses simulasi 
2. Tahap Latihan bagi Peserta didik

a. Membuat skenario yang berisi aturan peranan, langkah, pencatatan, bentuk keputusan yang harus dibuat, dan tujuan yang akan dicapai

b. 2) Menugaskan para pemeran dalam simulasi

c. 3) Mencoba secara singkat suatu eposide

3. Tahap Proses Simulasi

a. Melaksanakan aktivitas permainan dan pengaturan kegiatan terseut

b. Memperoleh umpan balik dan evaluasi dari hasil pengamatan terhadap performan si pemeran

c. Menjernihkan hal-hal yang miskonsepsional

d. Melanjutkan permainan/simulasi

4. Tahap Pemantapan (debriefing)

a. Memberikan ringkasan mengenai kejadian dan persepsi yang timbul selama simulasi

b. Memberikan ringkasan mengenai kesulitan-kesulitan dan wawasan para peserta

c. Menganalisis proses

d. Membandingkan aktivitas simulasi dengan dunia nyata

e. Menghubungkan proses simulasi dengan isi pelajaran

f. Menilai dan merancang kembali simulasi

\section{Media Gambar}

Media adalah perantara atau pengantar pesan dari pengirim sumber pesan kepada penerima pesan secara terminologi yang telah memperluas kemampuan manuasia untuk merasakan atau mendengar. Menurut Hamalik (2003 : 114) media adalah alat,metode dan teknik yang digunakan dalam rangka mengaktifkan komunikasi dan interaksi guru dan peserta didik dalam proses pembelajaran. Bahwa media pembelajaran merupakan sarana atau bentuk komunikasi yang merupakan wadah informasi.

Ada beberapa macam media pembelajaran antara lain:

1. Media visual yang tidak diproyeksikan ( gambar, ilustrasi, karikatur, poster, bagan, diagram, grafik dan peta ) 
2. Media audio ( wawancara, berita, radiao, warta berita, drama radio

3. diskusi dan seminar).

4. Media visual yang diproyeksikan (Over Head, Projector, slide proyektor)

5. Media cetak ( buku pelajaran, modul, majalah, surat kabar ).

Media gambar adalah suatu media visual yang hanya dapat dilihat saja, akan tetapi tidak mengandung unsur suara atau audio. Media realita adalah suatu media mengandung benda-benda yang nyata saat digunakan dalam pembelajaran. Misal contohnya : Hewan dan Tumbuh-tumbuhan yang hidup. Selanjutya Hamalik (2008 :43) berpendapat bahwa gambar adalah segala sesuatu yang diwujudkan secara visual dalam bentuk dua dimensi sebagai curahan perasaan atau pikiran.

Meskipun demikian, media gambar tidaklah sepenuhnya sempurna. Artinya, media gambar ini mempunyai kelebihan dan kekurangan. Menurut Purwanto dan Alim (1997:63), kelebihan media gambar adalah:

1. Sifatnya konkrit, gambar lebih realistis menunjukkan pokok masalah dibandingkan dengan media verbal semata.

2. Gambar dapat mengatasi batas ruang dan waktu.

3. Medai gambar dapat mengatasi keterbatasan pengamatan.

4. Dapat memperjelas suatu masalah dalam bidang apa saja.

5. Murah harganya, mudah diperoleh dan digunakannya.

Adapun kelemahan dari media gambar menurut Purwanto dan Alim (1997 : 63) antara lain adalah:

1. Media gambar menekankan persepsi indra mata.

2. Gambar yang terlalu kompleks kurang efektif untuk kegiatan pembelajaran.

3. Ukurannya sangat terbatas untuk kelompok besar.

Dari definisi diatas secara khusus media gambar berfungsi untuk menarik perhatian para peserta didik dalam pembelajaran dikelas. Pada penelitian ini penulis menggunakan dua metode gambar dan media gambar peta 


\section{PELAKSANAAN PENELITIAN PERBAIKAN PEMBELAJARAN}

\section{A. Subjek, Tempat, dan Waktu Penelitian}

\section{Subjek dan Tempat Penelitian}

Subjek penelitian adalah peserta didik kelas VI B yang berjumlah 25 orang. Peserta didik terdiri dari 10 laki-laki dan 15 perempuan pada mata pelajaran IPS tentang "Negara-negara tetangga di kawasan Asia Tenggara"

Adapun tempat dilakukannya penelitian adalah Sekolah Dasar Islam (SDI) Al Bayyinah yang beralamat di Jl. RM Kahfi II Cipedak Jagakarsa Jakarta Selatan.

\section{Waktu Penelitian}

Penelitian ini dilaksanakan mulai hari Rabu, 20 Juli 2019 yang diawali dengan prasiklus yang menjadi sumber masalah yang ditemukan. Kemudian dilanjutkan perbaikan pembelajaran siklus I pada hari Rabu tanggal 27 Juli 2019. Selanjutnya perbaikan pembelajaran siklus 2 pada har Jum'at tanggal 12 Agustus 2019.

\section{Pihak yang Membantu}

Adapun pihak-pihak yang membantu terlaksananya Penelitian Tindakan Kelas ini antara lain:

1. Bapak H. Marjuki, S.Pd selaku Kepala Sekolah Dasar Islam (SDI) Al Bayyinah.

2. Ibu Mariyantiningsih, S.Pd sebagai supervisor 2

\section{B. Desain Prosedur Perbaikan Pembelajaran}

\section{Siklus I}

\section{a. Persiapan}

1) Perencanaan pelaksanaan pembelajaran yang akan dilaksanakan pada hari Rabu tanggal 27 Juli 2019.

2) Guru menyusun rencana pembelajaran IPS dengan tema "Negaranegara tetangga di kawasan Asia Tenggara".

3) Penyususnan metode pembelajaran tambahan berupa metode simulasi dari sebelumnya metode ceramah dan tanya jawab.

4) Persiapan sumber belajar dan bahan ajar serta pembagian kelompok. 
5) Penyusunan alat evaluasi pembelajaran atau lembar kerja siswa.

\section{b. Pelaksanaan}

1) Kegiatan Awal ( \pm 10 menit)

a. Guru bersama peserta didik berdo'a bersama dipimpin oleh ketua kelas.

b. Guru mengkondisikan peserta didik di dalam kelas dan mempersiapkan materi ajar.

2) Kegiatan Inti ( \pm 40 menit)

a. Guru mengelompokkan peserta didik, tiap kelompok terdiri atas 3 orang peserta didik.

b. Guru memberikan materi pada tiap kelompok dan dipresentasikan dengan metode simulasi di depan kelas yang diwakili oleh satu orang setiap kelompoknya.

c. Guru mengamati proses simulasi dan peserta didik lainnya memperhatikan.

d. Guru menyampaikan arti negara tetangga.

3) Kegiatan Akhir ( \pm 20 menit)

a. Guru bersama peserta didik menyimpulkan pelajaran yang sudah disimulasikan oleh tiap kelompok.

b. Guru memberikan tugas berupa LKS terkait materi baru yang dipelajari.

c. Peserta didik mengerjakan tugas soal latihan.

d. Guru menutup pembelajaran diakhiri dengan do'a.

\section{c. Pengamatan}

Berdasarkan pengamatan dan observasi saat guru mengajar, yang menjadi permasalahan dalam pembelajaran tersebut adalah:

1. Peserta didik masih kurang termotivasi dalam pembelajaran.

2. Nilai rata-rata kelas yang diperoleh 67,5 masih di bawah KKM yaitu 70. Peserta didik yang mendapat nilai sesuai atau lebih dari KKM berjumlah 12 orang dari 25 peserta didik. Namun demikian, hasil siklus I ini lebih baik dari pada hasil pada pra siklus. 
3. Tanggung jawab peserta didik masih kurang saat diberikan tugas, karena belum dilaksanakan secara optimal.

4. Pada siklus I ini peneliti belum menggunakan media, sehingga pembelajaran masih kurang maksimal.

\section{d. Refleksi}

Dari pelaksanaan pembelajaran siklus I, ditemukan kelemahan dan kelebihan dalam tindakan perbaikan pembelajaran diantaranya:

1. Kelemahan

a. Guru masih kurang memandu peserta didik.

b. Aktifitas peserta didik belum semua terlibat.

c. Belum semua peserta didik mengerti dengan tugasnya.

d. Pembelajaran masih didominasi peserta didik yang aktif saja.

e. Perolehan hasil rata-rata kelas masih di bawah KKM yaitu 67,5 sedangkan KKM adalah 70. Peserta didik yang mendapat nilai sesuai atau lebih dari KKM berjumlah 12 orang dari 25 peserta didik, sehingga perlu dilanjutkan ke siklus berikutnya yaitu siklus II.

2. Kelebihan

a. Guru sudah mengeksplor peserta didik, melatih tanggung jawab, dan keberanian peserta didik dalam mempresentasikan materi

b. Peserta didik mampu menguasai materi yang sudah diberikan.

c. Pembelajaran lebih efektif dengan metode simulasi.

d. Pemahaman materi oleh peserta didik sedikit lebih baik.

\section{Siklus 2}

a. Persiapan

1) Perencanaan pelaksanaan pembelajaran yang akan dilaksanakan pada hari Jum'at tanggal 12 Agustus 2019.

2) Pada pertemuan sebelumnya, guru menugaskan peserta didik simulasi untuk mempresentasikan materi yang sudah ditugaskan pada setiap kelompok. 
3) Peserta didik ditugaskan membawa media gambar peta untuk ditampilkan pada simulasi berikutnya.

4) Persiapan sumber belajar dan bahan ajar.

5) Persiapan alat evaluasi berupa soal latihan.

b. Pelaksanaan

1) Kegiatan Awal ( \pm 10 menit)

a. Guru bersama peserta didik berdo'a bersam dipimpin oleh ketua kelas.

b. Guru mengkondisikan peserta didik untuk siap belajar.

c. Guru mengabsen peserta didik.

2) Kegiatan Inti ( \pm 40 menit)

a. Peserta didik pada tiap kelompok ditugaskan mengidentifikasikan negara-negara tetangga di kawasan Asia Tenggara dan mempresentasikannya dengan metode simulasi di depan kelas.

b. Peserta didik lainnya ikut merespon tiap simulasi kelompok lainnya melaui tanya jawab seputar materi yang disampaikan.

c. Guru mengamati kembali tiap kelompok peserta didik melakukan simulasi dengan lembar pengamatan dan penilaian yaitu:

1. Simulasi

2. Rangkuman

3. Peta

3) Kegiatan Akhir ( \pm 20 menit)

a. Guru beserta peserta didik menyimpulkan pembelajaran dengan pertanyaan-pertanyaan seputar materi negara-negara tetangga di kawasan Asia Tenggara.

b. Guru memberikan tes untuk mengetahui tingkat penguasaan peserta didik terhadap materi pelajaran.

c. Pengamatan 
Peneliti melakukan pengamatan terhadap aktifitas peserta didik dalam mengikuti perbaikan pembelajaran dengan metode simulasi. Dari hasil pengamatan ternyata ada perubahan yang sangat beda. Peserta didik lebih aktif, antusias, dan mengerti serta memahami materi yang telah dipelajari.

Hal ini tentu saja berpengaruh besar terhadap hasil belajar peserta didik yang meningkat dibandingkan dengan siklus I (nilai rerata 67,5) dengan siklus II (rerata 76.96) hal ini dikarenakan:

1. Guru sudah menggunakan media pembelajaran yang sesuai secara maksimal, sehingga terciptanya suasana pembelajaran yang kondusif dan menyenangkan bagi peserta didik.

2. Guru sudah menggunakan metode dan teknik pembelajaran yang efektif.

3. Guru sudah memberikan motivasi pada saat pembelajaran berlangsung sehingga peserta didik menjadi tertarik dengan pelajaran IPS

4. Guru sudah memberikan reward secara langsung selama pembelajaran, sehingga peserta didik menjadi aktif.

\section{d. Refleksi}

Dalam melakukan refleksi perbaikan pembelajaran, peneliti dan teman sejawat mencatat beberapa hal yang sangat berpengaruh pada penerapan metode simulasi melalui media gambar yaitu:

1. Dengan menggunakan metode simulasi peserta didik mendapatkan suasana baru, sehingga dapat menghindari kebosanan dalam proses pembelajaran.

2. Dengan menggunakan metode simulasi dapat membiasakan peserta didik untuk berkomunikasi aktif dalam bertukar pikiran dengan teman-temannya.

3. Melalui metode simulasi, peserta didik diajarkan untuk belajar tampil di depan kelas untuk melatih keberanian dan bertanggung jawab pada tugasnya masing-masing. 
4. Dengan metode simulasi melalui media gambar pada perbaikan pembelajaran pada siklus II ini hasil nilai rerata peserta didik sebesar $84 \%$ dan 21 dari 25 peserta didik yang mendapat nilai di atas KKM. Sedangkan hasil pengamatan didapat data peserta didik yang dapat menjawab pertanyaan guru dengan benar sebanyak 21 peserta didik atau sebesar $84 \%$.

\section{Teknik Analisis Data}

Berdasarkan pengamatan dan observasi, saat guru mengajar yang menjadi permasalahan dalam pembelajaran tersebut adalah:

1. Data Observasi

Sumber data dalam penelitian adalah peserta didik di kelas VI Sekolah Dasar Islam (SDI) Al Bayyinah Cipedak Jagakarsa Jakarta Selatan. Sedangkan jenis data yang diharapkan yaitu meliputi hasil observasi terhadap proses belajar dan data siswa.

2. Teknik Pengumpulan Data

a. Observasi

Observasi dilakukan untuk mengamati aktivitas belajar peserta didik.

b. Jurnal Harian

Jurnal harian merupakan catatan harian pada penelitian untuk merekam semua kegiatan dalam proses pembelajaran.

c. Data Tes Kemampuan pada Siklus I dan II

Data tes merupakan data kuantitatif yang diambil dari setiap siklus melalui post test.

3. Analisis Data

a. Data Observasi

Data ini diambil dari pengamatan yang dilakukan oleh peneliti sebagai orang yang terlibat aktif dalam pelaksanaan tindakan kelas dibantu teman sejawat yang telah bersedia menjadi supervisor 2 .

b. Data Tes Kemampuan 
Data tes kemampuan pada setiap siklus diakumulasikan pada setiap tabel, kemudian dihitung rata-rata hasil tes setiap pertemuan.

\section{HASIL PENELITIAN DAN PEMBAHASAN}

A. Deskripsi Hasil Penelitian Perbaikan Pembelajaran

Penelitian Tindakan Kelas ini, dilakukan oleh peneliti dibantu supervisor dalam mengobservasi dan memberikan masukan terhadap pelaksanaan pembelajaran yang dilakukan. Setelah selesai proses pembelajaran, maka dilakukan diskusi dengan supervisor untuk menemukan kekurangan-kekurangan peserta didik maupun guru dalam proses pembelajaran yang sudah dilaksanakan. Selanjutnya dilakukan refleksi terhadap pembelajaran yang telah dilaksanakan untuk mengambil tindakan tindakan perbaikan pembelajaran selanjutnya. Adapun instrumen yang disiapkan oleh peneliti sebagai berikut:

1. Instrumen pengamatan untuk mengetahui hasil belejar peserta didik.

2. Instrumen pengamatan peserta didik yang dapat menjawab pertanyaan guru.

3. Lembar evaluasi per siklus.

Dalam pelaksanaan pembelajaran pra siklus dengan KKM 70 di Sekolah Dasar Islam (SDI) Al Bayyinah Cipedak Jagakarsa Jakarta Selatan kelas VI pada mata pelajaran IPS tentang "Negara-negara tetangga di kawasan Asia Tenggara" dari 25 peserta didik diperoleh hasil rerata peseta didik 61,4 dengan perincian sebagai berikut. Jumlah nilai keseluruhan 1.535, nilai tertinggi 90 dan nilai terendah 23.8 orang peserta didik mencapai KKM atau $32 \%$. Sedangkan yang belum mencapai KKM berjumlah 17 orang peserta didik atau 68\%. Dalam kegiatan pembelajaran pada pra siklus ini sangatlah kurang memuaskan, karena jauh dari KKM.

Dalam pelaksanaan pembelajaran siklus I di Sekolah Dasar Islam (SDI) Al Bayyinah Cipedak Jagakarsa Jakarta Selatan kelas VI mata pelajaran IPS tentang "Negara-negara tetangga di kawasan Asia Tenggara" 
dengan KKM 70 dari jumlah 25 orang peserta didik diperoleh hasil rerata 67.56 dengan perincian jumlah nilai keseluruhan 1.689. Nilai tertinggi 90, dan nilai terendah 50. Peserta didik yang mencapai KKM berjumlah 13 orang atau $52 \%$. Sedangkan peserta didik yang belum mencapai KKM berjumlah 12 orang atau $48 \%$

Melalui data pengamatan peserta didik yang dapat menjawab pertanyaan guru hanya ada 13 orang peserta didik atau $52 \%$, sedangkan yang tidak dapat menjawab pertanyaan guru terdapat 12 orang peserta didik atau sebesar $48 \%$.

Dalam pelaksanaan pembelajaran siklus 2 di Sekolah Dasar Islam (SDI) Al Bayyinah Cipedak Jagakarsa Jakarta Selatan kelas VI mata pelajaran IPS tentang "Negara-negara tetangga di kawasan Asia Tenggara" dengan KKM 70 dari jumlah 25 peserta didik diperoleh hasil rerata 76,96 dengan perincian sebagai berikut, Jumlah nilai keseluruhan 1.924, nilai tertinggi 92 dan nilai terendah 65. Peserta didik yang mencapai KKM berjumlah 21 orang atau $84 \%$. Sedangkan yang belum mencapai KKM berjumlah 4 orangpeserta didik atau $16 \%$. Melalui data pengamatan yang dapat menjawab pertanyaan guru berjumlah 21 orang atau $84 \%$, sedangkan yang tidak dapat menjawab pertanyaan guru berjumlah 4 orang atau $16 \%$.

Berikut ini hasil rekapitulasi data nilai dan hasil pengamatan setiap siklus peserta didik pada mata pelajaran IPS di Sekolah Dasar Islam (SDI) Al Bayyinah Cipedak Jagakarsa Jakarta Selatan kelas VI dalam bentuk tabel:

Tabel 11

Rekapitulasi Data Hasil Belajar Pra Siklus, Siklus I, Siklus II

\begin{tabular}{|c|l|c|c|c|c|}
\hline No & \multicolumn{1}{|c|}{ Nama } & L/P & Pra Siklus & Siklus I & Siklus II \\
\hline 1 & Adinda Dwi A & P & 53 & 63 & 68 \\
\hline 2 & Agan Agiansyah & L & 53 & 53 & 65 \\
\hline 3 & Dimas Aji Satrio & L & 56 & 56 & 72 \\
\hline 4 & Dimas Pratama F & L & 90 & 90 & 90 \\
\hline 5 & Dina Hardianti & P & 60 & 60 & 65 \\
\hline 6 & Fallah Noor H & L & 50 & 50 & 71 \\
\hline
\end{tabular}




\begin{tabular}{|c|c|c|c|c|c|}
\hline 7 & Firman Valerian & $\mathrm{L}$ & 86 & 87 & 86 \\
\hline 8 & Gama Al Farobi & $\mathrm{L}$ & 73 & 73 & 82 \\
\hline 9 & Irfan Saputra & $\mathrm{L}$ & 63 & 73 & 75 \\
\hline 10 & Kartika Elia Putri & $\mathrm{P}$ & 73 & 73 & 78 \\
\hline 11 & Lia Amelia & $\mathrm{P}$ & 56 & 56 & 70 \\
\hline 12 & M. Taufik S & $\mathrm{L}$ & 70 & 73 & 83 \\
\hline 13 & Maesya Anggiska & $\mathrm{P}$ & 46 & 70 & 81 \\
\hline 14 & Mutiara Damayanti & $\mathrm{P}$ & 60 & 65 & 84 \\
\hline 15 & Nabila Nurrahma & $\mathrm{P}$ & 46 & 55 & 72 \\
\hline 16 & Putri Mutya & $\mathrm{P}$ & 66 & 72 & 79 \\
\hline 17 & Sagita Pradyaningrum & $\mathrm{P}$ & 23 & 71 & 90 \\
\hline 18 & Sheila Dyana Putri & $\mathrm{P}$ & 76 & 76 & 72 \\
\hline 19 & Shintia Aliza F & $\mathrm{P}$ & 46 & 55 & 69 \\
\hline 20 & Siti Najwa Hanifah & $\mathrm{P}$ & 53 & 55 & 69 \\
\hline 21 & Siti Zhafirah H & $\mathrm{P}$ & 80 & 82 & 92 \\
\hline 22 & Syahrul Ramadhan & $\mathrm{L}$ & 60 & 65 & 75 \\
\hline 23 & Taufik Hidayat & $\mathrm{L}$ & 80 & 89 & 73 \\
\hline 24 & Zahra Aisyah Derian & $\mathrm{P}$ & 60 & 64 & 70 \\
\hline 25 & Zahra Putri Nabila & $\mathrm{P}$ & 56 & 72 & 80 \\
\hline \multicolumn{3}{|c|}{ Jumlah Nilai } & 1.535 & 1.689 & 1.924 \\
\hline \multicolumn{3}{|c|}{ Nilai Tertinggi } & 90 & 90 & 92 \\
\hline \multicolumn{3}{|c|}{ Nilai Terendah } & 23 & 50 & 65 \\
\hline \multicolumn{3}{|c|}{ Nilai Rata-rata } & 61.44 & 67.56 & 76.96 \\
\hline \multicolumn{3}{|c|}{ Tuntas } & $8 \quad(32 \%)$ & $13(52 \%)$ & $21(84 \%)$ \\
\hline \multicolumn{3}{|c|}{ Tidak Tuntas } & $17(68 \%)$ & $12(48 \%)$ & $4(16 \%)$ \\
\hline
\end{tabular}

Tabel 12

Data Rekapitulasi Pengamatan Hasil Belajar pada Pra siklus, Siklus I, Siklus II

\begin{tabular}{|c|l|c|c|c|c|c|c|c|}
\hline \multirow{2}{*}{ No } & & \multirow{2}{*}{ L/ } & \multirow{2}{*}{\begin{tabular}{c} 
Nama \\
\cline { 5 - 11 }
\end{tabular}} & & Pra Siklus & \multicolumn{2}{c|}{ Siklus I } & \multicolumn{2}{c|}{ Siklus II } \\
\hline & & M & TM & M & TM & M & TM \\
\hline 1 & Adinda Dwi A & P & & $\sqrt{ }$ & & $\sqrt{ }$ & & $\sqrt{ }$ \\
\hline 2 & Agan Agiansyah & L & & $\sqrt{ }$ & & $\sqrt{ }$ & & $\sqrt{ }$ \\
\hline 3 & Dimas Aji Satrio & L & & $\sqrt{ }$ & & $\sqrt{ }$ & $\sqrt{ }$ & \\
\hline 4 & Dimas Pratama F & L & $\sqrt{ }$ & & $\sqrt{ }$ & & $\sqrt{ }$ & \\
\hline 5 & Dina Hardianti & P & & $\sqrt{ }$ & & $\sqrt{ }$ & $\sqrt{ }$ & \\
\hline 6 & Fallah Noor H & L & & $\sqrt{ }$ & & $\sqrt{ }$ & $\sqrt{ }$ & \\
\hline 7 & Firman Valerian & L & $\sqrt{ }$ & & $\sqrt{ }$ & & $\sqrt{ }$ & \\
\hline 8 & Gama Al Farobi & L & $\sqrt{ }$ & & $\sqrt{ }$ & & $\sqrt{ }$ & \\
\hline 9 & Irfan Saputra & L & & $\sqrt{ }$ & $\sqrt{ }$ & & $\sqrt{ }$ & \\
\hline 10 & Kartika Elia Putri & P & $\sqrt{ }$ & & $\sqrt{ }$ & & $\sqrt{ }$ & \\
\hline 11 & Lia Amelia & P & & $\sqrt{ }$ & & $\sqrt{ }$ & $\sqrt{ }$ & \\
\hline 12 & M. Taufik S & L & $\sqrt{ }$ & & $\sqrt{ }$ & & $\sqrt{ }$ & \\
\hline
\end{tabular}




\begin{tabular}{|c|c|c|c|c|c|c|c|c|}
\hline 13 & Maesya Anggiska & $\mathrm{P}$ & & $\sqrt{ }$ & $\sqrt{ }$ & & $\sqrt{ }$ & \\
\hline 14 & Mutiara Damayanti & $\mathrm{P}$ & & $\sqrt{ }$ & & $\sqrt{ }$ & $\sqrt{ }$ & \\
\hline 15 & Nabila Nurrahma & $\mathrm{P}$ & & $\sqrt{ }$ & & $\sqrt{ }$ & $\sqrt{ }$ & \\
\hline 1 & Putri Mutya & $\mathrm{P}$ & & $\sqrt{ }$ & $\sqrt{ }$ & & $\sqrt{ }$ & \\
\hline 17 & Sagita Pradyaningrum & $\mathrm{P}$ & & $\sqrt{ }$ & $\sqrt{ }$ & & $\sqrt{ }$ & \\
\hline 18 & Sheila Dyana Putri & $\mathrm{P}$ & $\sqrt{ }$ & & $\sqrt{ }$ & & $\sqrt{ }$ & \\
\hline 19 & Shintia Aliza F & $\mathrm{P}$ & & $\sqrt{ }$ & & $\sqrt{ }$ & & $\sqrt{ }$ \\
\hline 20 & Siti Najwa Hanifah & $\mathrm{P}$ & & $\sqrt{ }$ & & $\sqrt{ }$ & & $\sqrt{ }$ \\
\hline 21 & Siti Zhafirah H & $\mathrm{P}$ & $\sqrt{ }$ & & $\sqrt{ }$ & & $\sqrt{ }$ & \\
\hline 22 & Syahrul Ramadhan & $\mathrm{L}$ & & $\sqrt{ }$ & & $\sqrt{ }$ & $\sqrt{ }$ & \\
\hline 23 & Taufik Hidayat & $\mathrm{L}$ & $\sqrt{ }$ & & $\sqrt{ }$ & & $\sqrt{ }$ & \\
\hline 2 & Zahra Aisyah Derian & $\mathrm{P}$ & & $\sqrt{ }$ & & $\sqrt{ }$ & $\sqrt{ }$ & \\
\hline 25 & Zahra Putri Nabila & $\mathrm{P}$ & & $\sqrt{ }$ & $\sqrt{ }$ & & $\sqrt{ }$ & \\
\hline \multicolumn{3}{|c|}{ Jumlah } & 8 & 17 & 13 & 12 & 21 & 4 \\
\hline \multicolumn{3}{|c|}{ Prosentase } & $32 \%$ & $\begin{array}{l}68 \\
\%\end{array}$ & $52 \%$ & $\begin{array}{l}48 \\
\%\end{array}$ & $84 \%$ & $\begin{array}{l}16 \\
\%\end{array}$ \\
\hline
\end{tabular}

Ket:

M : Mampu menjawab

TM : Tidak mampu menjawab

\section{B. Pembahasan Hasil Penelitian Perbaikan Pembelajaran}

Dalam pelaksanaan pembelajaran pra siklus dengan KKM 70 di Sekolah Dasar Islam (SDI) Al Bayyinah Cipedak Jagakarsa Jakarta Selatankelas VI mata pelajaran IPS tentang " Negara-negara Tetangga di kawasan Asia Tenggara" dari jumlah 25 peserta didik hasil rerata 61,4 dengan perincian data sebagai berikut, jumlah nilai keseluruhan 1.535, nilai tertnggi 90 dan nilai terendah 23. 8 orang peserta didik mencapai KKM atau $32 \%$ sedangkan yang belum mencapai KKM berjumlah 17 peserta didik atau $68 \%$. Sedangkan melalui pengamatan peserta didik yang dapat menjawab pertanyaan guru terdapat hanya 8 orang peserta didik atau $32 \%$, sedangkan yang tidak dapat menjawab petanyaan guru terdapat 17 orang peserta didik atau $68 \%$. Dalam kegiatan pembelajaran pra siklus ini sangat kurang memuaskan.

Pada pembelajaran pra siklus ini nilai rerata pembelajaran IPS di bawah KKM, sehingga prestasi belajar masih rendah. Hal ini disebabkan kurangnya 
motivasi dari guru. Peserta didik menjadi pasif dan rasa tanggung jawab terhadap tugas-tugas masih rendah. Penyebab faktor tersebut adalah:

1. Guru belum menggunakan metode pembelajaran yang tepat. Guru hanya menggunakan metode ceramah pada pembelajaran yang sesuai secara maksimal sehingga tidak terciptanya suasana pembelajaran yang kondusif dan menyenangkan bagi peserta didik.

2. Guru belum menggunakan media disaat pembelajaran berlangsung, sehingga peserta didik tidak tertarik pada pelajaran IPS.

3. Guru kurang memotivasi pada saat pembelajaran, sehingga terlihat peserta didik menjadi pasif.

Pada pelaksanaan pembelajaran siklus I dengan KKM 70 di Sekolah Dasar Islam (SDI) Al Bayyinah Cipedak Jagakarsa Jakarta Selatankelas VI mata pelajaran IPS tentang " Negara-negara Tetangga di kawasan Asia Tenggara" dari jumlah 25 peserta didik hasil rerata 67,56 dengan perincian data sebagai berikut, jumlah nilai keseluruhan 1.689, nilai tertnggi 90 dan nilai terendah 50. Peserta didik mencapai KKM berjumlah 13 orang atau 52 $\%$ sedangkan yang belum mencapai KKM berjumlah 12 orang peserta didik atau $48 \%$. Melalui pengamatan peserta didik yang dapat menjawab pertanyaan guru terdapat hanya 13 orang peserta didik atau $52 \%$, sedangkan yang tidak dapat menjawab petanyaan guru terdapat 12 orang peserta didik atau $48 \%$. Walaupun ada peningkatan tetapi hasil rerata peserta didik belum mencapai KKM.

Penyebab rendahnya prestasi belajar peserta didik pada siklus I adalah guru belum melakukan hal-hal berikut:

1. Guru belum menggunakan metode yang tepat pada saat pembelajaran yang sesuai secara maksimal, sehingga tidak tercipta suasana pembelajaran yang kondusif.

2. Guru belum menggunakan media pembelajaran yang sesuai dengan materi pembelajaran.

3. Guru kurang memotivasi pada saat pembelajaran berlangsung, sehingga peserta didik tidak tertarik pada pelajaran IPS. 
Dengan demikian, maka peneliti melakukan penelitian pada siklus II untuk mengatasi masalah di siklus I. Adapun yang peneliti lakukan adalah sebagai beruikut:

1. Menggunakan metode simulasi pada pembelajaran dan teknik pembelajaran yang bervariasi dan efektifmenggunakan alat peraga.

2. Menggunakan media pembelajaran yang sesuai secara maksimal sehingga mempermudah peserta didik memahami materi pelajaran dan tercipta suasana pembelajaran yang menyenangkan bagi peserta didik yaitu dengan metode simulasi melalui media gambar.

3. Memberikan motivasi pada saat pembelajaran berlangsung sehingga peserta didik tertarik saat pembelajaran IPS.

Dalam pelaksanaan pembelajaran siklus II peneliti menambahkan metode simulasi melalui media gambar peta. Hasil yang didapat adalah dari jumlah 25 peserta didik diperoleh hasil rerata 76.96 dengan rincian sebagai berikut, jumlah nilai keseluruhan 1924, nilai tertinggi 92, nilai terendah 65 , peserta didik yang mencapai KKM berjumlah 21 orang atau $84 \%$, sedangkan yang belum mencapai KKM berjumlah 4 orang atau $16 \%$. Melalui pengamatan peserta didik yang dapat menjawab pertanyaan guru berjumlah 21 orang atau $84 \%$ sedangkan yang tidak dapat menjawab pertanyaan guru terdapat 4 orang peserta didik atau $16 \%$.

Dalam kegiatan pembelajaran pada siklus II ini peserta didik sangat antusias dan termotivasi untuk mengikuti pelajaran IPS. Hal ini disebabkan karena guru sudah menggunakan metode dan media yang tepat dan sesuai dengan materi yang diajarkan selama proses belajar mengajar berlangsung, sehingga tercipta suasana belajar yang merangsang dan menyenangkan bagi peserta didik.

Ketika peneliti menggunakan metode simulasi dan media gambar yang tepat, banyak peserta didik yang tertantang untuk berani tampil ke depan kelasmenjelaskan materi yang ditugaskan. Sangat terlihat jelas peserta didik yang berani dan siap, sehingga mereka mampu menjawab soal latihan dari materi penjelasan peneliti sehingga memberikan hasil yang meningkat. Dalam 
hal ini peneliti sangat menyadari bahwa perlunya pemilihan metode dan media yang tepat pada pembelajaran dan mencatat antusias peserta didik lebih meningkat dalam memahami pelajaran IPS.

Tidak kalah penting lagi memotivasi peserta didik dalam belajar. Salah satunya yang digunakan yaitu menyediakan summber belajar, penggunaan metode dan media yang tepat dan sesuai serta melibatkan peserta didik dalam proses pembelajaran berlangsung.

Kemampuan dasar guru yang paling utama dalam meraih keberhasilan para peserta didik adalah guru mampun dan sanggup menggunakan metode mengajar yang tepat dan sesuai dengan kebutuhan para peserta didik. Selain itu guru juga harus memiliki kemampuan mengajar dan menguasai materi dengan baik, senantiasa berusaha mengeksplor potensi peserta didik sehingga hasil yang didapat peserta didik adalah suasana yang menyenangkan. Belajar tidak lagi monoton dan tidak menimbulkan kejenuhan bagi peserta didik, dan yang menjadi tujuan bersama yaitu keberhasilan bagi peserta didik tercapai.

\section{KESIMPULAN DAN SARAN TINDAK LANJUT}

\section{A. Simpulan}

Berdasarkan hasil Penelitian Tindakan Kelas (PTK) melalui kegiatan perbaikan pembelajaran yang telah dilaksanakan mulai dari pra siklus, siklus I, sampai siklus II pada mata pelajaran IPS, peneliti dapat menarik kesimpulan sebagai berikut:

1. Dalam melaksanakan prasiklus dengan KKM 70 di Sekolah Dasar Islam (SDI) Al Bayyinah Ciprdak Jagakarsa Jakarta Selatan kelas VI pada mata pelajaran Ilmu Pengetahuan Sosial tentang "Negara-negara tetangga di kawasan Asia Tenggara" dari 25 peserta didik diperoleh hasil rerata 61,4 dengan peserta didik yang mencapai KKM 8 orang peserta didik atau $32 \%$. Sedangkan melalui data pengamatan peserta didik yang dapat menjawab pertanyaan guru hanya 8 peserta didik atau $32 \%$. Siklus I hasil rerata 67,56 yang mencapai KKM berjumlah 12 orang peserta didik atau $48 \%$. Sedangkan melalui data pengamatan 
peserta didik yang dapat menjawab pertanyaan guru hanya 13 orang peserta didik atau $52 \%$. Dalam pelaksanaan pembelajaran siklus II diperoleh hasil rerata peserta didik 76,96. Peserta yang mencapai KKM berjumlah 21 orang peserta didik atau $84 \%$. Sedangkan data pengamatan peserta didik yang dapat menjawab pertanyaan guru berjumlah 21 orang peserta didik atau $84 \%$.

2. Dengan demikian pemilihan metode simulasi melalui media gambar peta dapat memberikan pengaruh yang sangat besar dengan meningkatkan hasil belajar, motivasi, tanggung jawab terhadap tugas menjadi tinggi serta membantu peserta didik untuk terlibat aktif di dalam kelas.

\section{B. Saran dan Tindak Lanjut}

Berdasarkan pada kesimpulan di atas, ada beberapa hal yang sebaiknya dilakukan guru dalam upaya meningkatkan hasil belajar peserta didik, diantaranya:

1. Guru mampu melakukan pemilihan metode yang tepat . dengan metode simulasi melalui gambar peta dapat membantu peserta didik untuk lebih mudah memahami materi pelajaran.

2. Motivasi yang tinggi sangat dibutuhkan oleh peserta didik sebelum melakukan pembelajaran.

3. Suasana belajar yang menyenangkan di kelas dapat membangkitkan gairah peserta didik dalam belajar.

4. Melibatkan peserta didik untuk lebih aktif di kelas, serta menumbuhkan rasa percaya diri yang tinggi dan keberanian peserta didik dalam menyampaikan pendapat dan memberi penjelasan dalam belajar.

\section{DAFTAR PUSTAKA}

Ali, Muhammad. (1983). Guru Dalam Proses belajar Mengajar. Bandung : Sinar Baru Algensindo 
Anitah, Sri W. dkk, (2013) Strategi Pembelajaran di SD, Tanggerang Selatan : Universitas Terbuka

Anni, Catharina Tri. dkk. (2006). Psikologi Belajar. Semarang : Universitas Negeri Semarang Press.

Ahmadi, Abu. (2009). Ilmu Sosial Dasar . Jakarta : Rineka Cipta

Hamalik, Umar. (2002). Perencanaan Pengajaran Berdasarkan Pendekatan Sistem. Jakarta: PT. Bumi Aksara

Joyce, Bruce, dkk. (2009). Models of Teaching: Model-Model Pengajaran. Yogyakart: Pustaka Pelajar

Jihad Asep, Abdul Haris. (2013). Evaluasi Pembelajaran. Yogyakarta: Multi Pressindo

Mulyani Sumantri dan Johar Permana,. (1998/1999). Strategi Belajar Mengajar. Jakarta: Departemen Pendidikan Kebudayaan Direktorat Pendidikan Tinggi Proyek Pendidikan Guru Sekolah Dasar

Pasaribu, L.L.(1993). Proses Belajar Mengajar. Bandung : PT. Remaja Rosda Karya.

Poerwadarminta, W.J.S, (2005). Kamus Besar Bahasa Indonesia Edisi Ketiga. Jakarta : Balai Pustaka.

Purwanto, M. Ngalim \& Djeniah Alim. (1997). Metodologi Pengajaran Bahasa Indonesia di Sekolah Dasar. Jakarta : PT. Rosda Jaya Putra.

Sudirman, Sudirman \& Sulfemi, Wahyu Bagja. (2010). Korelasi Antara Konsep Diri Guru dengan Profesionalisme Guru di SMA Negeri 1 Pamijahan Kabupaten Bogor. Edutecno 2 (2), 10-19

Sugiri, Sugiri \& Sulfemi, Wahyu Bagja. (2011). Pendidikan Multi Kultur di Sekolah Berbasis Keagamaan. Edutecno. 3 (2), 11-20.

Slameto. (2003), Belajar dan Fakta yang Mempengaruhinya. Jakarta : Rineka Cipta

Supriya, (2009). Pendidikan IPS. Bandung: PT Remaja Rosda Karya.

Syah, Muhibbin. (2004), Psikologi Pendidikan dengan Pendekatan Baru. Bandung : Remaja Rosdakarya.

Sardiyo, dkk. (2009). Pendidikan IPS di SD. Tanggerang Selatan : UniversitasTerbuka

Syaiful Bahri Djamarah, \& Aswan Zain. (2010). Strategi Belajar-Mengajar (revisi). Jakarta: Rineka Cipta

Sa'ud, Udin Syaefudin. (2005) Perencanaan Pendidikan Pendekatan Komprehensif. Bandung: PT Remaja Rosdakarya. 
Sulfemi, Wahyu Bagja. (2009). Modul Pembelajaran Pendidikan Pancasila dan Kewarganegaraar. Bogor : STKIP Muhammadiyah Bogor.

Sulfemi, Wahyu Bagja dan Supriyadi, Dede. (2018). Pengaruh Kemampuan Pedagogik Guru dengan Hasil Belajar IPS. Edutecno 17 (1), 1-10.

Sulfemi, Wahyu Bagja dan Lestari, Ayu Hopilatul. (2017). Korelasi Kompetensi Pedagogik Guru dengan Prestasi Belajar Mata Pelajaran IPS Di SMP Muhammadiyah Pamijahan Kabupaten Bogor. Edutecno. 16 (1), 1-16.

Sulfemi, Wahyu Bagja dan Abdul Qodir. (2017). Hubungan Kurikulum 2013 Dengan Motivasi Belajar Peserta Didik Di SMK Pelita Ciampea. Edutecno 17 (2), 1-8

Sulfemi, Wahyu Bagja. (2017). Analisis Pengaruh Motivasi Dan Disiplin Terhadap Kinerja Guru (Studi Kasus di SMA Negeri 1 Pamijahan Kabupaten Kabupaten Bogor). Prosiding Seminar Nasonal STKIP Muhammadiyah Bogor. 1 (1), 342-357.

Sulfemi, Wahyu Bagja. (2018). Manajemen Kurikulum di Sekolah. Bogor : Visi Nusantara Maju

Sulfemi, Wahyu Bagja. (2018). Hubungan Motivasi Belajar Dengan Hasil Belajar IPS Di SMP Kabupaten Bogor. Edutecno 18 (2), 1-8.

Sulfemi, Wahyu Bagja dan Nurhasanah. (2018). Penggunaan Metode Demontrasi dan Media Audio Visual Dalam Meningkatkan Hasil Belajar Peserta Didik Mata Pelajaran IPS. Jurnal Pendas Mahakam. 3 (2). 151-158.

Sulfemi, Wahyu Bagja dan Hilga Minati. (2018). Meningkatkan Hasil Belajar Peserta Didik Kelas 3 SD Menggunakan Model Picture And Picture dan Media Gambar Seri. JPSD. 4 (2), 228- 242.

Sulfemi, Wahyu Bagja dan Setianingsih. (2018), Penggunaan Tames Games Tournament (TGT) Dengan Media Kartu Dalam Meningkatkan Hasil Belajar. Journal of Komodo Science Education (JKSE. 1 (1), 1-14

Sulfemi, Wahyu Bagja. (2018). Pengaruh Disiplin Ibadah Sholat, Lingkungan Sekolah, dan Intelegensi Terhadap Hasil Belajar Peserta Didik Mata Pelajaran Pendidikan Agama Islam. Edukasi: Jurnal Penelitian Pendidikan Agama dan Keagamaan. 16 (2), 166-178

Sulfemi, Wahyu Bagja. (2018). Modul Manajemen Pendidikan Non Formal. Bogor: STKIP Muhammadiyah Bogor.

Sulfemi, Wahyu Bagja dan Mayasari, Nova. (2019). Peranan Model Pembelajaran Value Clarification Technique Berbantuan Media Audio Visual Untuk Meningkatkan Hasil Belajar IPS. Jurnal Pendidikan. 20. (1). 53-68.

Sulfemi, Wahyu Bagja., \& Yuliana, Desi. (2019). Penerapan Model Pembelajaran Discovery Learning Meningkatkan Motivasi dan Hasil Belajar 
Pendidikan Kewarganegaraan. Jurnal Rontal Keilmuan Pancasila dan Kewarganegaraan. 5 (1), 17-30.

Sulfemi, Wahyu Bagja (2019). Model Pembelajaran Kooperatif Mind Mapping Berbantu Audio Visual Dalam Meningkatkan Minat, Motivasi dan Hasil Belajar IPS. Jurnal Pendidikan Ilmu Pengetahuan Sosial Indonesia (PIPSI). 4 (1), $13-19$.

Sulfemi, W. B. (2019). Modul Pembelajaran Perundang-Undangan Pendidikan. Bogor : STKIP Muhammadiyah Bogor

Taniredja, Tukiran, dkk. (2011). Model-Model Pembelajaran Inovatif. Bandung: Alfabeta

Uno, Hamzah B \&Nurdin Muhamad (2011). Belajar dengan Pendekatan PAILKEM:Pembelajaran Aktif, Inovatif, Lingkungan, Kreatif, Efektif, Menarik. Jakarta:PT. Bumi Aksara

Winataputra, Udin S. (2000). Model-Model Pembelajaran Inovatif. Jakarta: Dirjen Pendidikan Tinggi

Yusfiriadi, Yusfiriadi, \& Sulfemi, Wahyu Bagja. (2011). Pemberdayaan Unit Produksi Melalui Pendekatan Manajemen Stratejik di SMK Pertiwi Kabupaten Bogor. Edutecno. 3 (1), 1-10.

Yusfiriadi, Yusfiriadi, \& Sulfemi, Wahyu Bagja. (2012). Penyelewangan Dana Dalam Dunia Pendidikan. Fascho 1 (1), 1-9 